\title{
Intersyngenic Variations in the Esterases and Acid Phosphatases of Tetrahymena pyriformis
}

\author{
Sally Lyman Allen ${ }^{1}$ and Sharon L. Weremiuk ${ }^{1}$
}

Received 15 July 1970-Final 12 Nov. 1970

The esterase and acid phosphatase isozymes were surveyed in strains of syngens 2-12 under conditions found to be optimal for syngen 1. Both intersyngenic and intrasyngenic variations were found. Comparisons of the esterases suggest that homologous enzymes are present in certain syngens and that some ordering of the variations with respect to syngen differences is possible. The acid phosphatases are highly polymorphic in different strains even within a syngen, and the variations cannot be ordered with respect to syngen differences. These results are discussed in terms of other types of studies directed at assessing syngen relationships and in terms of the sources of variation. It was concluded that only characters less vulnerable to intraclonal variation will be capable of revealing syngen relationships.

\section{INTRODUCTION}

The evolution of a group of organisms is a complex phenomenon and operates on the products of many interacting genes. The phenotype of an organism is its target, but, more specifically, evolution acts upon the varying phenotypes of populations of organisms. Characters under stringent selection tend to be conserved in a population, while those under less stringent selection vary more widely. The observed rates of divergence within a group thus depend upon the characters examined and the degree to which change is tolerated.

Evolution can be examined at different levels of organization with the ultimate aim of understanding the kinds and rates of change that occur in the genes of an organism. At the molecular level, these questions can be approached in various ways. Studies on rates of reassociation of DNA in solution can tell us something about the organization

\footnotetext{
Supported by a Research Grant, GM-15879, from the National Institute of General Medical Sciences, U.S. Public Health Service.

1 Departments of Botany and Zoology, The University of Michigan, Ann Arbor, Michigan.
} 
of the DNA in the genome in different species during evolution (Britten and Kohne, 1968). Which fractions and which portions of the genome are conserved or vary in different species can then be determined by in vitro tests of DNA homologies McCarthy, 1967; Walker, 1969). The proteins are images of parts of the genome, and comparisons of proteins in different species provide some clues as to the the types of change permitted in the genome which result in constancy or variation in the structure and function of the molecule. Comparisons of amino acid sequences in a single protein in a variety of organisms provide some measure of the types of change tolerated in a gene which are compatible with function. Certain sequences are conserved while other sequences vary depending upon their location in three-dimensional space in the folded protein molecule. Rates of evolution can be computed from amino acid substitutions (Margoliash and Smith, 1965). Another approach is the examination of functionally related molecules, such as the isozymes of a given enzyme, in different species. The extent of variation and duplication of molecules is a measure of the evolution of the part of the genome concerned with specifying proteins.

The most common technique for studying isozyme variations is the zymogram method (see Shaw and Koen, 1968). In this method, molecules are compared by their electrophoretic mobilities and their affinities for particular substrates. In lieu of genetic data, chemical methods are used for the identification of molecules. Molecules with similar mobilities and chemical properties are assumed to be genetically identical; those with different mobilities but similar chemical properties are assumed to be homologous forms due to "allelic" differences, while those with different chemical properties are assumed to be nonhomologous even if they have similar mobilities. There are certain limitations to this method. Since only a third of the base substitutions lead to alterations in net charge, we will be underestimating the total amount of variation in any comparison. We also recognize that the appearance or activity of a molecule depends not only on the presence of its structural gene(s) but that it may also depend upon the state of functioning of one or more regulatory genes. The use of breeding analysis, growth under different conditions, etc., helps to sort out the contributions made by different genes and regulatory molecules, but it is not always possible to obtain this type of information.

We have been concerned with examining the isozymes of different enzymes in groups of related ciliated protozoa. We would like to know the extent of isozyme variation within a breeding population and among populations which do not crossbreed. Are these variations correlated with the degree of gene flow and can they give a measure of evolutionary distance between populations which have become genetically isolated over the historical past?

Several "species" of ciliated protozoa are, in fact, species complexes which contain populations of animals which cannot interbreed in the laboratory and which can coexist in nature without gene exchange. From the genetic point of view, these are biological species. These breeding groups have been referred to as syngens by Sonneborn (1957). We have been concerned with two of these species complexes: Tetrahymena pyriformis, with 12 syngens, and Paramecium aurelia, with 14 syngens. We have been interested in the extent of isozyme variation within and among syngens in each species complex and whether the degree of variation is similar in Tetrahymena 
and Paramecium. We have examined the esterases in both species complexes and the acid phosphatases in Tetrahymena. With the "unnatural" substrates commonly used in the zymogram technique, it is often difficult to classify these enzymes, and opinion differs as to whether the electrophoretically separated forms are isozymes (Markert, 1968; Shaw, 1969). Specificity can be introduced by the use of different substrates and inhibitors. The virtue of using enzymes such as the esterases is that a broad spectrum of molecules can be surveyed simultaneously. We do recognize, however, that the electrophoretic patterns are complex and require patient analysis before separating out the types and sources of variation. Our approach has been to examine at least two strains (or stocks) in each syngen and to compare the patterns within a syngen and among syngens. This paper reports our observations on Tetrahymena. The following three papers are devoted to Paramecium.

There are 12 breeding groups, or syngens, of $T$. pyriformis. Morphologically similar, they vary in the details of their breeding systems, in temperature tolerance, in nutritional requirements, and in their geographic distribution (Elliott, 1971). Syngens 1-8 are found in North America; syngen 2 is also found in Central America, syngen 3 in Europe, syngen 4 in England, continental Europe, and Asia, and syngen 6 in England, continental Europe, and Africa. Syngen 9 has been collected in Central and South America and certain Pacific islands, while the syngen 10 collections have been restricted to three southern counties in England. Syngens 11 and 12 are found in Australia. No mating or gene flow occurs between any of the syngens, except for syngens 6 and 8, which were shown to mate and yield some viable offspring (Orias, 1959).

In this paper, our approach has been to examine the esterase and acid phosphatase isozymes of representative strains of each of the syngens and to compare them to the isozymes of syngen 1, which have been studied previously (Allen, 1965, 1968). What is the extent of the variation among different strains and are the variations ordered with respect to syngen differences?

\section{MATERIALS AND METHODS}

\section{Strains}

At least two strains from each of the 12 syngens were surveyed in this study. Table I lists the strain designations, geographic origin, and "code" for each strain. The code letters are used in the photographs. Many of these strains are "wild" strains which were initiated from single cells isolated from ponds, lakes, or streams. A few strains are the progeny derived from crosses of wild strains. Strains 7 and 8 of syngen 1 , are homozygous strains derived by genomic exclusion (Allen, 1967); strain (7/8)7 is heterozygous for the three genes $E-1, E-2$, and $P-1$ in syngen 1 (see Allen and Gibson, $1971 a$, for a review of the genetics of Tetrahymena).

All the strains except for those of syngen 1 were kindly supplied by Dr. A. M. Elliott (University of Michigan). They were identified as to their syngen classification on the basis of the mating reaction. They were grown in $1 \%$ proteose-peptone at $23 \mathrm{C}$ and maintained by biweekly subculture. 
Table I. Strains in Syngens of T. pyriformis

\begin{tabular}{|c|c|c|c|c|}
\hline Syngen & Strain & $\begin{array}{c}\text { Syngen/ } \\
\text { mating type }\end{array}$ & $\begin{array}{l}\text { Geographic } \\
\text { origin }\end{array}$ & Code \\
\hline 1 & $\begin{array}{l}\# 7 / V \\
\# 8 / I \\
\#(7 / 8) 7\end{array}$ & $\begin{array}{l}1 / \mathrm{V} \\
1 / \mathrm{I} \\
1 / \text { immature }\end{array}$ & $\begin{array}{l}\text { U.S.-derived } \\
\text { U.S.-derived } \\
\text { U.S.-derived }\end{array}$ & $\begin{array}{r}1 \mathrm{a} \\
\mathrm{b} \\
\mathrm{c}\end{array}$ \\
\hline 2 & $\begin{array}{l}\text { UM-3 } \\
\text { UM-457 } \\
\text { H } \\
\text { UM-351 } \\
\text { HAM-3 }\end{array}$ & $\begin{array}{l}2 / \mathrm{I} \\
2 / \mathrm{II} \\
2 / \mathrm{III} \\
2 / \mathrm{IV} \\
2 / \mathrm{IX}\end{array}$ & $\begin{array}{l}\text { Massachusetts } \\
\text { Oklahoma } \\
\text { Derived } \\
\text { Michigan } \\
\text { Texas }\end{array}$ & $\begin{array}{c}2 \mathrm{a} \\
\mathrm{b} \\
\mathrm{c} \\
\mathrm{d} \\
\mathrm{e}\end{array}$ \\
\hline 3 & $\begin{array}{l}\text { UM-700 } \\
\text { UM-705 } \\
F_{2}-666 \\
F_{2}-665 \\
U M-787\end{array}$ & $\begin{array}{l}3 / \mathrm{I} \\
3 / \mathrm{II} \\
3 / \mathrm{IV} \\
3 / \mathrm{V} \\
3 / \mathrm{VII}\end{array}$ & $\begin{array}{l}\text { Mississippi } \\
\text { Mississippi } \\
\text { Derived } \\
\text { Derived } \\
\text { Michigan }\end{array}$ & $\begin{array}{r}3 a \\
b \\
c \\
d \\
e\end{array}$ \\
\hline 4 & $\begin{array}{l}\text { UM-913 } \\
\text { IN-3 } \\
\text { IN-2 }\end{array}$ & $\begin{array}{l}4 / \mathrm{I} \\
4 / \mathrm{II} \\
4 / \mathrm{III}\end{array}$ & $\begin{array}{l}\text { Minnesota } \\
\text { India } \\
\text { India }\end{array}$ & $\begin{array}{r}4 a \\
b \\
c\end{array}$ \\
\hline 5 & $\begin{array}{l}\text { UM-24 } \\
\text { UM-30 }\end{array}$ & $\begin{array}{l}5 / \mathrm{I} \\
5 / \mathrm{II}\end{array}$ & $\begin{array}{l}\text { Massachusetts } \\
\text { Massachusetts }\end{array}$ & $\begin{array}{r}5 a \\
b\end{array}$ \\
\hline 6 & $\begin{array}{l}\text { UM-1060 } \\
\text { UM-1091 } \\
\text { UM-1147 }\end{array}$ & $\begin{array}{l}6 / I \\
6 / I I \\
6 / I I I\end{array}$ & $\begin{array}{l}\text { Michigan } \\
\text { Florida } \\
\text { Derived }\end{array}$ & $\begin{array}{r}6 a \\
b \\
c\end{array}$ \\
\hline 7 & $\begin{array}{l}\text { UM-1215 } \\
\text { UM-1216 } \\
\text { UC-651 }\end{array}$ & $\begin{array}{l}7 / \mathrm{I} \\
7 / \mathrm{II} \\
7 / \mathrm{III}\end{array}$ & $\begin{array}{l}\text { North Carolina } \\
\text { North Carolina } \\
\text { California }\end{array}$ & $\begin{array}{r}7 \mathrm{a} \\
\mathrm{b} \\
\mathrm{c}\end{array}$ \\
\hline 8 & $\begin{array}{l}\text { O } \\
\text { UM-1286 } \\
\text { Alp-1 } \\
\text { R }\end{array}$ & $\begin{array}{l}8 / \mathrm{II} \\
8 / \mathrm{II} \\
8 / \mathrm{III} \\
8 / ?\end{array}$ & $\begin{array}{l}\text { Derived } \\
\text { Minnesota } \\
\text { Michigan } \\
\text { U.S. }\end{array}$ & $\begin{array}{r}8 \mathrm{a} \\
\mathrm{b} \\
\mathrm{c} \\
\mathrm{d}\end{array}$ \\
\hline 9 & $\begin{array}{l}\text { JK } \\
\text { TC-148 } \\
\text { TC-89 }\end{array}$ & $\begin{array}{l}9 / \mathrm{I} \\
9 / \mathrm{II} \\
9 / \mathrm{V}\end{array}$ & $\begin{array}{l}\text { Derived } \\
\text { Panama } \\
\text { Panama }\end{array}$ & $\begin{array}{r}9 a \\
b \\
c\end{array}$ \\
\hline 10 & $\begin{array}{l}\text { EN-112 } \\
\text { EN-131 }\end{array}$ & $\begin{array}{l}10 / I \\
10 / I I\end{array}$ & $\begin{array}{l}\text { England } \\
\text { England }\end{array}$ & $\begin{array}{r}10 a \\
b\end{array}$ \\
\hline 11 & $\begin{array}{l}\text { AU-1-2x } \\
\text { AU-50-1 } \\
\text { AU-94-10 }\end{array}$ & $\begin{array}{l}11 / \mathrm{I} \\
11 / \mathrm{II} \\
11 / \mathrm{III}\end{array}$ & $\begin{array}{l}\text { Australia } \\
\text { Australia } \\
\text { Australia }\end{array}$ & $\begin{array}{r}11 a \\
b \\
c\end{array}$ \\
\hline 12 & $\begin{array}{l}\mathrm{AU}-\mathrm{F}_{1} 2 \\
\mathrm{AU}-\mathrm{F}_{1} 4 \\
\mathrm{AU}-3-4 \\
\mathrm{AU}-\mathrm{F}_{1} 1 \\
\mathrm{AU}-115-3 \\
\mathrm{AU}-\mathrm{F}_{1} 3\end{array}$ & $\begin{array}{l}12 / \mathrm{I} \\
12 / \mathrm{I} \\
12 / \mathrm{II} \\
12 / \mathrm{III} \\
12 / \mathrm{IV} \\
12 / \mathrm{IV}\end{array}$ & $\begin{array}{l}\text { Australia } \\
\text { Australia } \\
\text { Australia } \\
\text { Australia } \\
\text { Australia } \\
\text { Australia }\end{array}$ & $\begin{array}{r}12 a \\
b \\
c \\
d \\
e \\
f\end{array}$ \\
\hline
\end{tabular}

\section{Growth of Cells for Extracts}

Two types of media were used: $1 \%$ proteose-peptone or skimmed milk (see addendum). Flask cultures ( $100 \mathrm{ml}$ in $250 \mathrm{ml}$ flask) were initiated from tubed cultures and grown for 10 days at $23 \mathrm{C}$. Such growth produces stationary cultures. Each extract 
was made from cells obtained from at least $200 \mathrm{ml}$ of culture. The cells were concentrated by centrifugation and broken up by repeated freeze-thawing. Extracts can be stored in a deep-freeze without loss of enzymatic activity for at least 1 year.

\section{Identification of Enzymes}

Starch gel electrophoresis was carried out by the procedures used for syngen 1 (esterases: Allen, 1964; acid phosphatases: Allen et al., 1963a). The propionylesterases were visualized in the gels by incubation at $p \mathrm{H} 7.4$ in $0.1 \mathrm{M}$ Sörensen's phosphate buffer in a reaction mixture containing $0.5 \mathrm{mM} \alpha$-naphthyl propionate, 1 $\mathrm{mM}$ sodium taurocholate, and $1 \mathrm{mg} / \mathrm{ml}$ Fast Blue RR (4'-amino 2', 5-dimethylbenzanilide; C.I. No. 37155) for $4 \mathrm{hr}$ at $30 \mathrm{C}$. The butyrylesterases were visualized by incubation at $p \mathrm{H} 6.5$ in 0.1 M Sörensen's phosphate buffer in a reaction mixture containing $1 \mathrm{~mm} \alpha$-naphthyl butyrate and $1 \mathrm{mg} / \mathrm{ml}$ Fast Blue RR for $2-3 \mathrm{hr}$ at $30 \mathrm{C}$ and overnight at $4 \mathrm{C}$. The acid phosphatases were revealed by incubation at $p \mathrm{H} 5.0$ in $0.05 \mathrm{M}$ acetate buffer in a reaction mixture containing $4 \mathrm{~mm}$ sodium $\alpha$ naphthyl phosphate and $1 \mathrm{mg} / \mathrm{ml}$ Fast Garnet GBC (4-amino $3: 1^{\prime}$-dimethyl azobenzene; C.I. 37210 ) for $30-60 \mathrm{~min}$ at $23 \mathrm{C}$.

Inhibitors were used as outlined in Allen $(1964,1965)$ and Allen et al. $(1963 a)$. The gels were preincubated in inhibitor for $30 \mathrm{~min}$, and the inhibitor was included in the reaction mixture.

The gels were rinsed with distilled water and stored in $7 \frac{1}{2} \%$ acetic acid until they were photographed.

Many comparisons were made beyond those illustrated in Fig. 2-4. All extracts from syngens $2-12$ were compared to the syngen 1 extracts on the same gel as well as to each other on other gels. The distance of each zone of activity from the origin was recorded in centimeters and compared to the "marker" isozymes present in syngen 1.

\section{RESULTS}

\section{Esterases}

\section{Syngen 1}

There are some 20-25 esterase isozymes in syngen 1 in different genotypes and under different conditions of growth using the two substrates $\alpha$-naphthyl propionate and $\alpha$-naphthyl butyrate (Allen, 1960, 1961, 1964, 1965, 1968). Some are less active and require special conditions or long periods of incubation in order to reveal them. Some split both substrates. Others are more specific and split only one of the substrates. Structural genes ( $E-1$ and $E-2)$ have been identified. for two sets of esterase isozymes (see Fig. 1a, b). The esterase-1 isozymes are propionylesterases, and are activated by sodium taurocholate and inhibited by eserine sulfate; each homozygote has five or six "secondary" isozymes which segregate as a unit in crosses. These are probably conformers, resulting from secondary changes in a single molecule, and their number varies depending upon the conditions of electrophoresis and the conditions under which the cells are grown. The activity of each conformer shifts during the growth cycle, and 


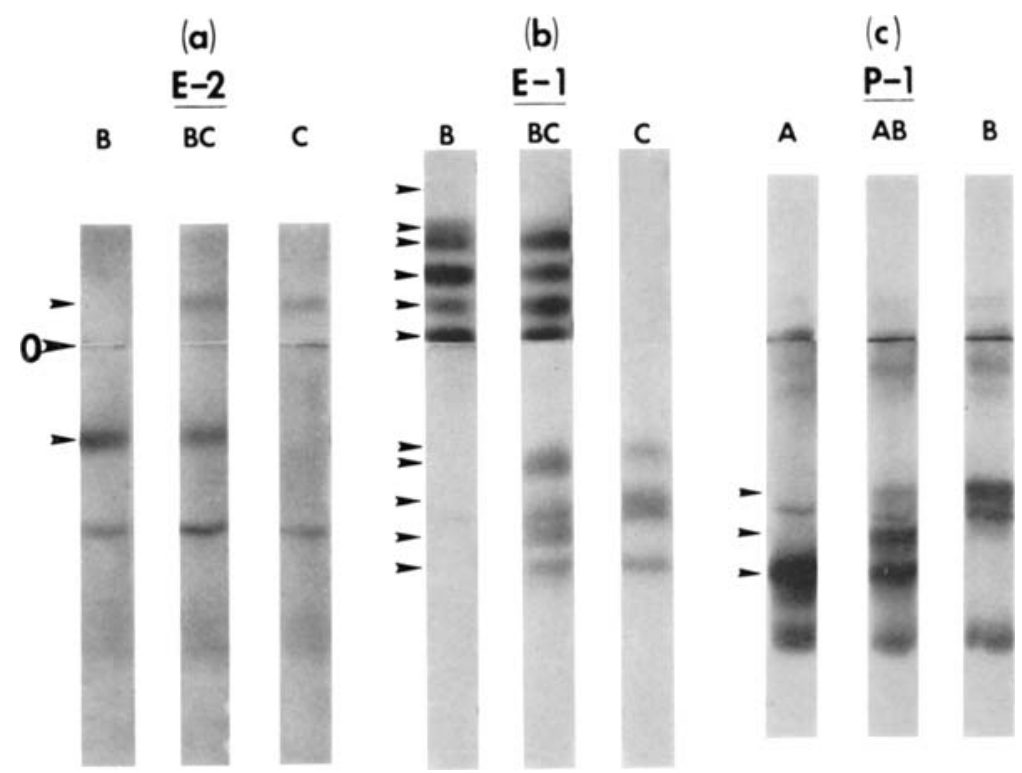

Fig. 1. Esterases and acid phosphatases in different genotypes of (a) $E-2$, (b) $E-1$, and (c) $P-I$ in syngen 1 . The cathode is at the top, the anode at the bottom, and the origin is indicated by $\mathbf{O}$. Specific sites of enzymatic activity are marked by arrows. The starch gels were incubated in (a) $\alpha$-naphthyl butyrate at $p \mathrm{H} 6.5$, (b) $\alpha$-naphthyl propionate at $p \mathbf{H} 7.4$, and (c) sodium $\alpha$-naphthyl acid phosphate at $p \mathbf{H} 5.0$.

complicated changes in activity are observed if the composition of the growth medium is altered. New conformers can be generated in vitro by addition of iodoacetamide. One of these secondary isozymes is present in the microsomes of each homozygote, and it is the first of the set to appear in logarithmically grown cells. The esterase-2 isozymes are butyrylesterases, insensitive to eserine, but are inactivated by $p$-chloromercuribenzoic acid. Little variation is observed in cells of different age or if the cells are grown in various media, but there appears to be an additional gene which affects activity (Allen and Lee, 1971). Esterases-3, -4, etc., are indicated by their different behavior toward various substrates and inhibitors. For example, esterase- 3 is found in all genotypes, splits both $\alpha$-naphthyl propionate and $\alpha$-naphthyl butyrate, is eserine insensitive, but is inactivated by $p$-chloromercuribenzoic acid and sodium taurocholate (at high concentrations).

\section{Other Syngens: Comparison to Syngen 1}

The propionylesterases and butyrylesterases of strains from syngens 2-12 were examined along with strains from syngen 1 . In these studies, we used the electrophoretic conditions we have found optimal for syngen 1, and all cultures were in the stationary phase of growth. Our approach was to compare the isozymes in the other groups to those in syngen 1 with respect to electrophoretic mobility and enzymatic properties. 


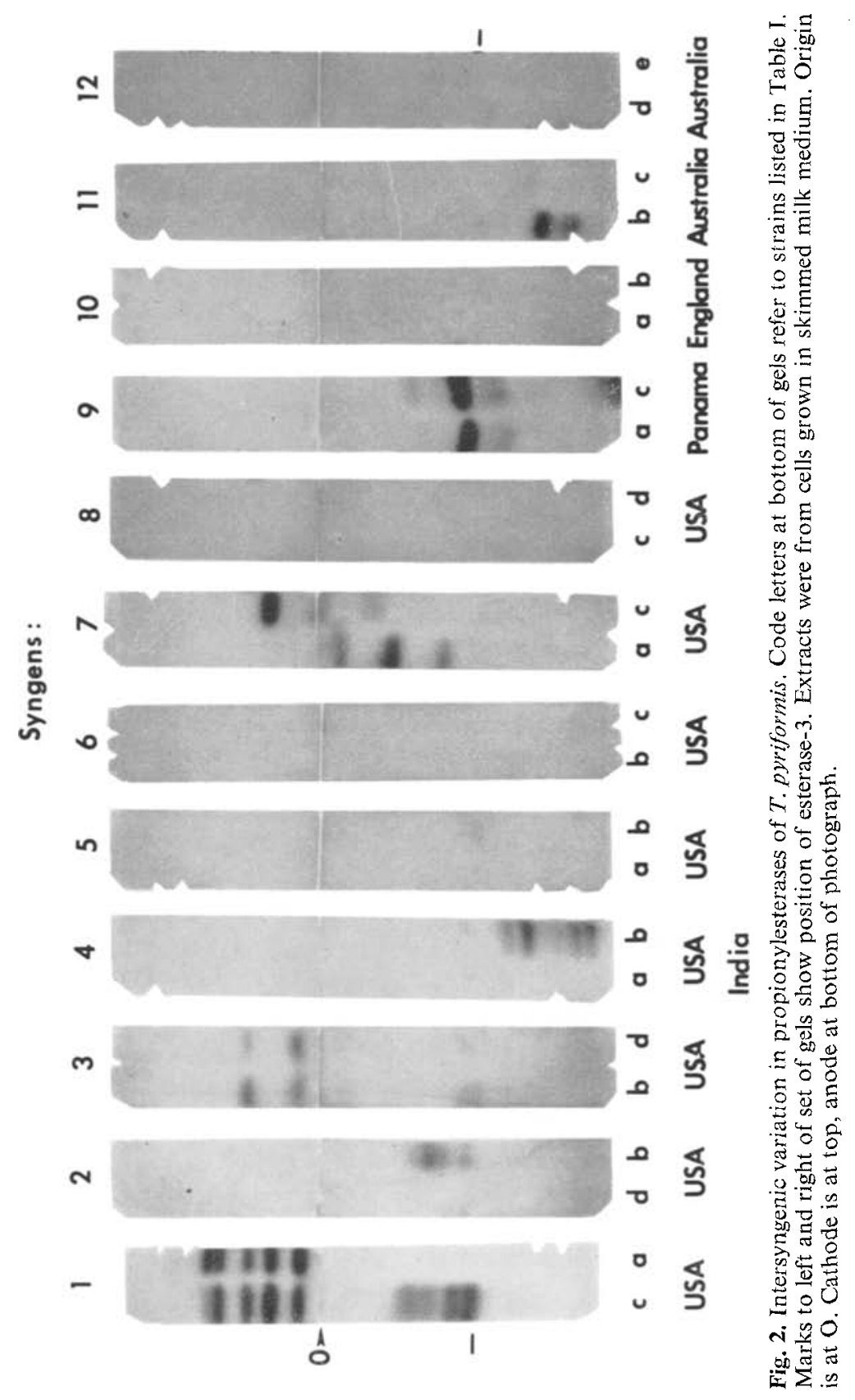




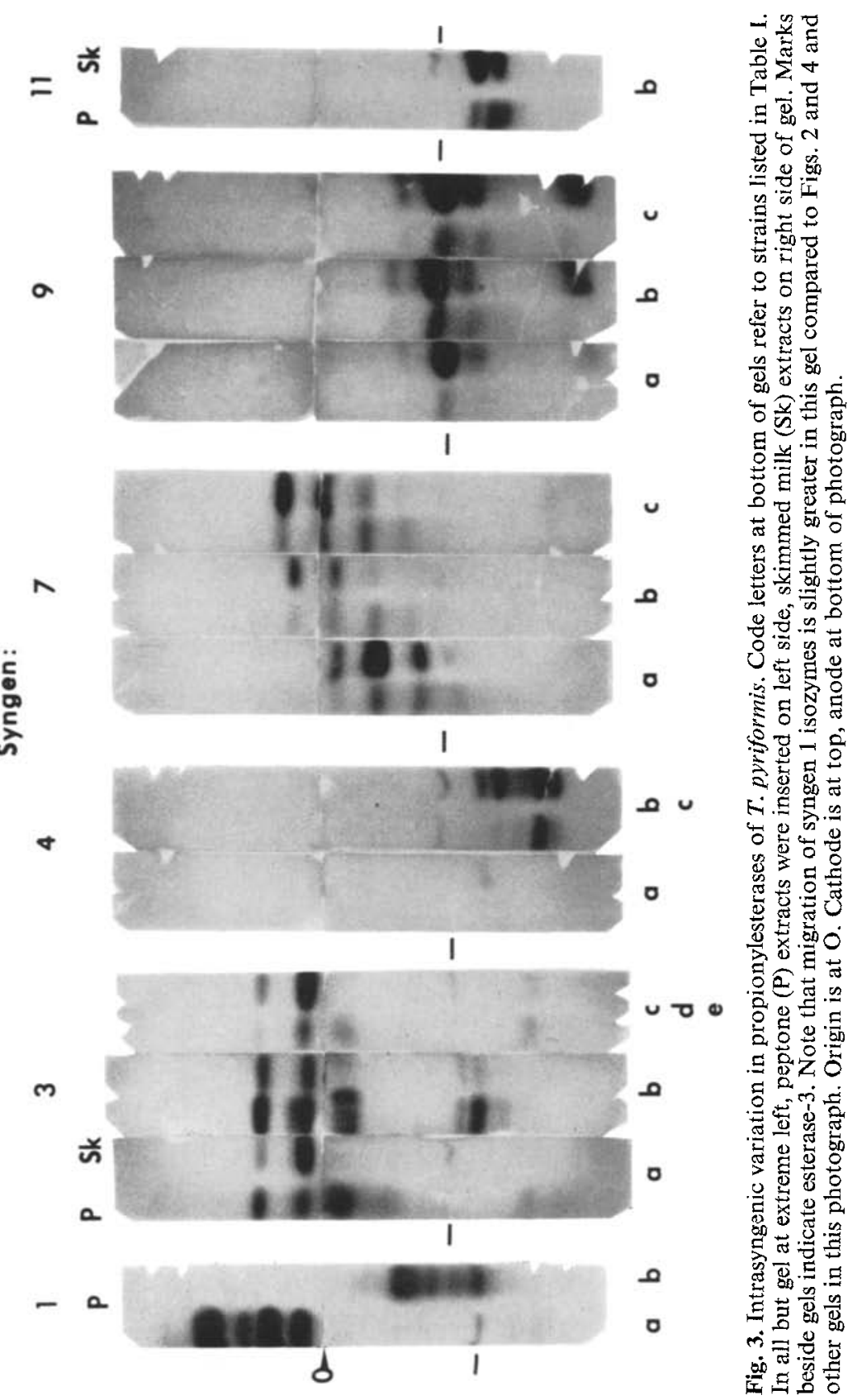


An esterase with similar electrophoretic mobility to esterase- 3 in syngen 1 appears in most of the other syngens (it is indicated by a mark beside the photographs of the gels in Figs. 2 and 3). It splits both $\alpha$-naphthyl propionate and $\alpha$-naphthyl butyrate, is eserine insensitive, but is inactivated by $p$-chloromercuribenzoic acid $\left(10^{-3} \mathrm{M}\right)$.

There also appear to be esterases similar to esterase-1 in some of the other syngens, namely, syngens $2,3,4,7,9$, and 11 (Fig. 2). This statement follows from the observation that they split $\alpha$-naphthyl propionate and not $\alpha$-naphthyl butyrate, that they are activated by sodium taurocholate $\left(10^{-3} \mathrm{M}\right)$, and that they are inhibited by eserine sulfate $\left(10^{-4} \mathrm{M}\right)$. They also seem to have conformers. We have tested the effects of iodoacetamide on extracts of syngens 4, 7, and 9, and "new" isozymes are produced, as observed for syngen 1 . They are also sensitive to conditions of growth, and more conformers appear when the cells are grown in skimmed milk medium than in peptone. This is shown in Fig. 3, where extracts from cells grown in $1 \%$ proteose-peptone (left) are compared side by side on the same gel with extracts from cells grown in skimmed milk (right). With some exception, the activity of the esterases is greater if the cells are grown in skimmed milk, and more conformers appear.

Certain esterases in syngens $2,4,7,9$, and 12 appear to be similar to esterase- 2 in syngen 1 . They split $\alpha$-naphthyl butyrate but not $\alpha$-naphthyl propionate. They are insensitive to eserine sulfate but are inactivated by $p$-chloromercuribenzoic acid $\left(10^{-3} \mathrm{M}\right)$.

At least one strain in syngens $2,3,4,7,9$, and 11 has several active propionylesterases, including esterase-1, and some butyrylesterases. The strains tested in syngen 12 have one or two propionylesterases of low activity and esterase- 2 and esterase- 3 . Syngen 5 has esterase- 3 and a few butyrylesterases of low activity. Syngens 6 and 8 have only one or two propionylesterases of low activity, but several butyrylesterases, also of low activity. Syngen 10 has esterase activity but no esterases that migrate under the conditions of electrophoresis. Table II summarizes the distribution of esterases-1, -2 , and -3 in the 12 syngens.

\section{Intrasyngenic Variation}

There is some intrasyngenic variation for the esterases, which differs in different syngens. It is most obvious for esterase-1 (Fig. 3). Little variation was observed between strains within syngens 3 and 9 , but in syngen 7 none of the three strains tested had the same set of esterase- 1 isozymes, and only one strain in syngens 2 and 11 had any esterase-1.

\section{Phosphatases}

Syngen 1

There are 18-20 phosphatase isozymes in syngen 1 in different genotypes and under different conditions of growth. These phosphatases vary in their activities with different substrates and inhibitors, and in their sensitivity to neutral and alkaline $p H$ (Allen et al., 1963a, $b$; Allen, 1965, 1968). A structural gene $(P-I)$ has been identified for phosphatase-1. There are two alleles, and interaction occurs in the heterozygote where as many as three hybrid enzymes may be observed. Phosphatase-1 appears to 
Table II. Distribution of Esterases-1, -2, and -3 Among Strains $^{a}$

\begin{tabular}{|c|c|c|c|}
\hline Strain & Esterase-1 & Esterase-2 & Esterase $-3^{b}$ \\
\hline $1 a$ & $+c$ & $+^{c}$ & + \\
\hline$b$ & + & + & + \\
\hline $\mathrm{c}$ & + & + & + \\
\hline $2 \mathrm{a}$ & - & $+^{c}$ & + \\
\hline b & + & + & + \\
\hline$c$ & - & + & + \\
\hline $\mathrm{d}$ & - & + & + \\
\hline $\mathrm{e}$ & - & + & + \\
\hline $3 a$ & + & - & + \\
\hline b & + & - & + \\
\hline $\mathrm{c}$ & + & - & + \\
\hline d & + & - & + \\
\hline $\mathrm{e}$ & + & - & + \\
\hline $4 a$ & $+^{c}$ & $+^{c}$ & + \\
\hline $\mathrm{b}$ & + & + & + \\
\hline $\mathrm{c}$ & + & + & + \\
\hline $5 \mathrm{a}$ & - & - & + \\
\hline $\mathbf{b}$ & - & - & + \\
\hline $6 \mathrm{a}$ & - & - & - \\
\hline b & - & - & - \\
\hline $\mathrm{c}$ & - & - & - \\
\hline $7 a$ & $+^{c}$ & + & + \\
\hline b & + & + & + \\
\hline $\mathrm{c}$ & + & + & + \\
\hline $8 \mathrm{a}$ & - & - & - \\
\hline b & - & - & - \\
\hline$c$ & - & - & - \\
\hline $\mathrm{d}$ & - & - & - \\
\hline $9 \mathrm{a}$ & + & + & + \\
\hline $\mathrm{b}$ & + & + & + \\
\hline$c$ & + & + & + \\
\hline $10 \mathrm{a}$ & - & - & - \\
\hline b & - & - & - \\
\hline $11 \mathrm{a}$ & - & - & + \\
\hline $\mathrm{b}$ & + & - & + \\
\hline $\mathrm{c}$ & - & - & + \\
\hline $12 \mathrm{a}$ & - & $+^{c}$ & + \\
\hline$b$ & - & + & + \\
\hline $\mathrm{c}$ & - & + & + \\
\hline $\mathrm{d}$ & - & + & + \\
\hline $\mathrm{e}$ & - & $t$ & + \\
\hline f & - & + & + \\
\hline \multicolumn{4}{|c|}{$\begin{array}{l}{ }^{a}+=\text { Enzymatic activity observed; }-=\text { no } \\
\text { detectable enzymatic activity. } \\
{ }^{b} \text { Where present, the mobility of esterase- } 3 \text { was } \\
\text { similar in all strains of species complex. } \\
{ }^{c} \text { Differences in mobility observed between } \\
\text { strains within the syngen. }\end{array}$} \\
\hline
\end{tabular}


be a lysosomal enzyme and is insensitive to $p$-chloromercuribenzoic acid. Figure 1c shows the typical isozyme patterns of different $P-1$ genotypes.

\section{Other Syngens: Comparison to Syngen 1}

The acid phosphatases of strains from syngens 1-12 are shown in Fig. 4. There is considerable acid phosphatase activity in all strains and all syngens. The same extracts (of cells grown in skimmed milk medium) that were used for resolving the esterases were used here, and the incubation time was $30 \mathrm{~min}$. Thus, our failure to detect esterase isozymes in some of these extracts does not appear to be due to some technical artifact but represents a real difference among strains and among syngens.

Some of the isozymes in other syngens seem to have similar mobilities to ones observed in syngen 1. However, $p$-chloromercuribenzoic acid inhibits the phosphatases in the other syngens we have examined (syngens 3, 4, 7, and 9), so we have not as yet obtained presumptive evidence for an enzyme in these syngens similar to phosphatase-1 in syngen 1, which is insensitive to this inhibitor. Syngens 2-12 differ from syngen 1 in their possession of one or more rapidly migrating cathodal isozymes. These are highly variable in number and position in different strains.

\section{Intrasyngenic Variation}

In general, there appears to be considerable polymorphism in the acid phosphatases in the species complex (see Fig. 4). Variations in the isozyme patterns are extensive not

\section{Syngens:}

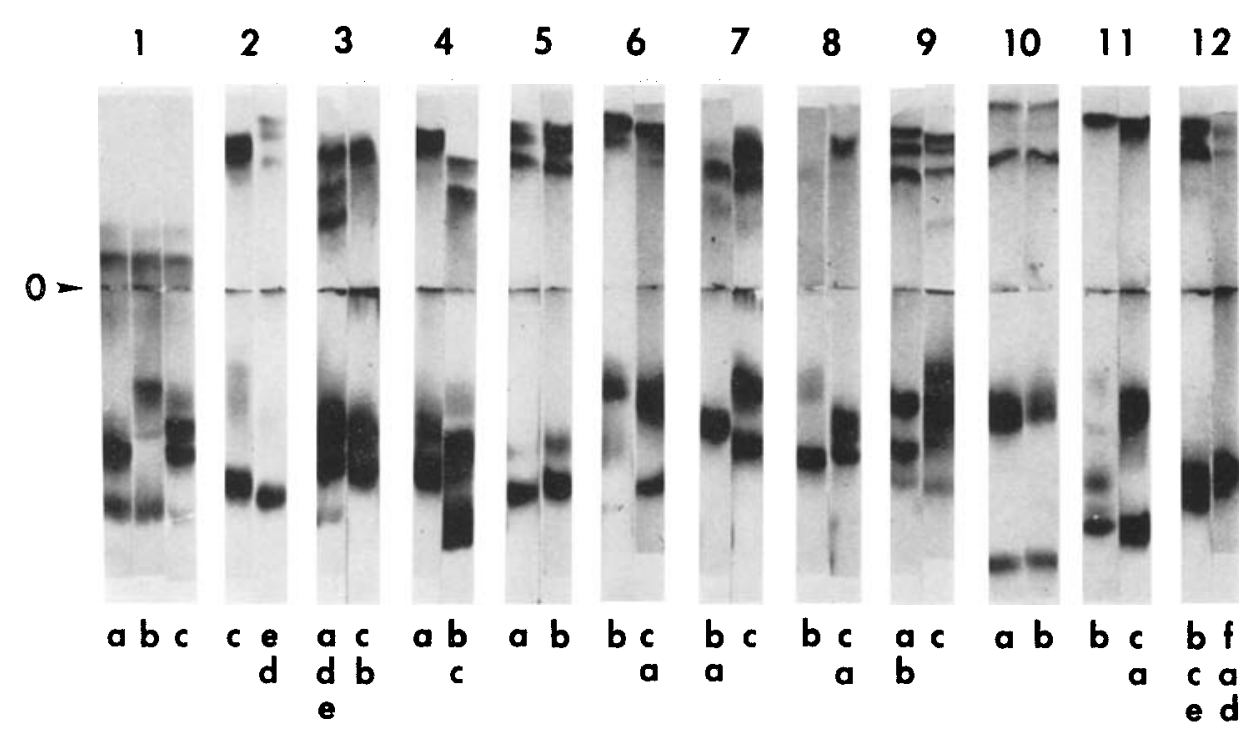

Fig. 4. Intersyngenic variation in acid phosphatases of T. pyriformis. Code letters at bottom of gels refer to strains listed in Table I. Extracts were from cells grown in skimmed milk medium. Origin is at $O$. Cathode is at top, anode at bottom of photograph. Gels from syngens $2-12$ have been selected with migrations corresponding to those seen on single gels run against syngen 1 . 
only among syngens but also within a syngen. Similar patterns within a syngen were observed only for the strains in syngens 5,10 , and 12. For all other syngens, at least one variant strain was observed

\section{Ordering of Variations with Respect to Syngen Differences}

We conclude that strains in different syngens have few acid phosphatases in common and that intrasyngenic variation is extensive. It would be difficult, indeed, to assign an unknown strain to a particular syngen on the basis of its acid phosphatase isozymes. The esterase isozymes also vary, but perhaps not as much as the acid phosphatases. Strains in different syngens have few esterases with similar electrophoretic mobility, but some are homologous enzymes. In general, the esterase differences among syngens are greater than within a sygnen. Intrasyngenic variation does occur, though perhaps not in all syngens. It might even be possible to assign an unknown strain to a particular syngen on the basis of its esterases if it happened to belong to syngen 3 or 9 .

\section{DISCUSSION}

The magnitude of the isozyme variations among different strains was surprising to us since the number of strains surveyed was small. Extensive variations occur within the same syngen. Thus, it is difficult to order the variations with respect to syngen differences, and even more difficult to assess relationships among syngens.

Strains are assigned to a particular syngen on the basis of the mating reaction. The mating reaction in itself is however not sufficient evidence that two strains belong to the same syngen. In $P$. aurelia intersyngenic matings are known, but these are not fruitful matings and fail to yield recombinants. Although capable of mating, the strains listed for syngens $2-12$ in Table I are now senile and do not produce viable progeny. It is therefore possible that more than 12 syngens are represented and that part of the variability which appears to be intrasyngenic may in some instances represent intersyngenic variation. This possibility then should be kept in mind for other strain characteristics which have been compared.

Cells in different syngens are morphologically similar and have the same number of micronuclear chromosomes. Yet they have been reported to vary in a number of parameters. Comparisons among syngens have been made in geographic distribution, cell size, temperature tolerance, nutritional requirements, mating-type inheritance, corticotypes, and nucleic acid homologies.

Of the 12 syngens recognized by Elliott (1971), some were collected in the same geographical area. Syngens 1-8 were found in North America, syngens 2 and 9 in Central America (and in the same pond), syngens 4, 6, and 10 in England, syngens 3, 4, and 6 in continental Europe, and syngens 11 and 12 in Australia.

Cell size ranges from 40 to $60 \mu$. According to Elliott (1971), the syngens can be ranked in the following order from largest to smallest: $6,9,8,12,11,7,4,3,5,2,1$, and 10. Elliott (1971) also reports differences in temperature tolerance and nutritional requirements. Syngens $2-11$ can withstand temperatures from 2-6 C to $37 \mathrm{C}$, syngen 12 has a narrow temperature tolerance range $(10-35 \mathrm{C})$, while syngen 1 survives 
temperatures between 10 and $40 \mathrm{C}$. Variations in nutritional requirements occur among strains in different syngens as well as within a syngen. Caryonidal inheritance for mating types occurs in syngens 1,3 , and 7 , while direct genic control occurs in syngen 8 and probably for 6 and 2 (reviewed in Allen and Gibson, 1971a). Corticotype relationships appear to agree with the classification based on mating-type inheritance. Thus, Nanney $(1967,1968)$ found that the first nine syngens could be ranked with respect to syngen 1 in the following order: 1, 3, 7, 6, 8, 9, 2, 5, and 4. A different relationship, however, was found in studies of in vitro hybridization of nucleic acid molecules (Allen and Gibson, 1967, 1971a). With respect to syngen 1, the syngens examined were ranked in the following order: $1,8,9,7,10,3$, and 12 . In this study, intrasyngenic variation was also observed.

How do the results of the present investigation fit in with the relationships suggested by comparisons of corticotype and mating-type inheritance? The acid phosphatase isozymes are too variable to make assessments of relationships. However, some ordering of the syngens is possible if the esterase isozymes are compared. Esterase-1 and esterase- 3 are found in syngens 3 and 7 , and esterase- 2 is also found in syngen 7. But esterase- 1 is also found in syngens $2,4,9$, and 11 , esterase- 2 in syngens $2,4,9$, and 12 , and esterase- 3 in all but 6,8 , and 10. The esterases of syngens 6 and 8 are somewhat similar, although the activities are really too low to make a meaningful comparison. Thus, there is some support for the suggested relationships. However, there are additional complexities. The complexities stem from the notable degree of intrasyngenic variation.

Most of the characters examined have shown this type of variation. Possibly only the most "conservative" characters ("essential" enzymes, etc.) or characters expected to be under multigenic control, such as mating-type inheritance, cell size, or temperature tolerance, may be less subject to intrasyngenic variation. Intrasyngenic variation could be attributed to several sources: to underclassification of the syngens, to genetic differences, to epigenetic differences, or to physiological variations induced by the environment. In syngens which have been studied genetically, variants have been found for different characters, including the esterases and acid phosphatases. For syngen 1, heterozygosity is common in nature (Phillips, 1968a; see also Allen and Gibson, 1971a). But - there is also another very important source of variation. Subclones of heterozygotes may express different phenotypes, often having phenotypes similar to those of homozygotes. Thus, intraclonal variation occurs in heterozygotes. It has been observed in syngen 1 (reviewed in Allen and Gibson, 1971a) and recently in syngen 7 (Phillips, 1968b). Intraclonal variation also occurs in homozygotes for mating types and for corticotypes. How widespread intraclonal variation is in the other syngens is not known. If it is of general occurrence in the species complex, then variations would be expected in all but the most conservative characters, or those characters under stringent selection.

This means that assessing syngen relationships and measuring evolutionary distance may be very difficult in T. pyriformis, if characters are selected which are subject to intraclonal variation. Evolutionary distances would tend to be overinflated. Perhaps application of the isozyme technique to more "conservative" enzymes might avoid this source of variation and yield more easily assessed relationships. 
It is curious that conservatism seems to exist in $P$. aurelia-even for the esterases. Here, the variations can be clearly ordered with respect to syngen differences (Allen et al., 1971; Allen and Gibson, 1971b). The significance of this difference between the two species complexes will be deferred until after a consideration of the esterase isozymes of $P$. aurelia.

\section{ADDENDUM}

The skimmed milk medium was developed by John C. Hegenaur. The components of the medium should be added in the order listed, with mechanical stirring, and should be brought to 1 liter volume in ion-free distilled water. The yield of cells is $3-5 \mathrm{ml}$ packed cells per liter of culture, or a three- to fivefold increase in the yield obtained from a liter of culture grown in $1 \%$ proteose-peptone.

\section{Formula}

Substance

Sodium $\beta$-glycerophosphate $5 \frac{1}{2} \mathrm{H}_{2} \mathrm{O}$

L-glutamic acid

Tris

Bacto-casitone

Bacto-yeast extract

Trace element solution

Pet nonfat dry milk

Amount per Liter
$1.0 \mathrm{~g}$
$0.5 \mathrm{~g}$
$1.5 \mathrm{~g}$
$5.0 \mathrm{~g}$
$3.0 \mathrm{~g}$
$1.0 \mathrm{ml}$
$30.0 \mathrm{~g}$

The $p \mathrm{H}$ is $7.6-7.7$.

\section{Formula for Trace Element Solution (1000X)}

$\begin{array}{lr} & \text { Substance } \\ \mathrm{FeCl}_{3} \cdot 6 \mathrm{H}_{2} \mathrm{O} & \text { Amount per Liter } \\ \mathrm{CuSO}_{4} \cdot 5 \mathrm{H}_{2} \mathrm{O} & 4500 \mathrm{mg} \\ \mathrm{MnCl}_{2} \cdot 4 \mathrm{H}_{2} \mathrm{O} & 8800 \mathrm{mg} \\ \mathrm{ZnSO}_{4} \cdot 7 \mathrm{H}_{2} \mathrm{O} & 50 \mathrm{mg} \\ \mathrm{CoCl}_{2} \cdot 6 \mathrm{H}_{2} \mathrm{O} & 110 \mathrm{mg} \\ \mathrm{K}_{2} \mathrm{~B}_{4} \mathrm{O}_{7} \cdot 4 \mathrm{H}_{2} \mathrm{O} & 100 \mathrm{mg} \\ \left(\mathrm{NH}_{4}\right)_{6} \mathrm{Mo}_{7} \mathrm{O}_{24} \cdot 4 \mathrm{H}_{2} \mathrm{O} & 25 \mathrm{mg} \\ \mathrm{HCl}(\text { concentrated) } & 25 \mathrm{mg}\end{array}$

\section{REFERENCES}

Allen, S. L. (1960). Inherited variations in the esterases of Tetrahymena. Genetics 45: 1051.

Allen, S. L. (1961). Genetic control of the esterases in the protozoan, Tetrahymena pyriformis. Ann. N.Y. Acad. Sci. 94: 753.

Allen, S. L. (1964). The esterase isozymes of Tetrahymena: Their distribution in isolated cellular components and their behavior during the growth cycle. J. Exptl. Zool. 155: 349.

Allen, S. L. (1965). Genetic control of enzymes in Tetrahymena. Brookhaven Symp. Biol. 18: 27. 
Allen, S. L. (1967). Genomic exclusion: A rapid means for inducing homozygous diploid lines in Tetrahymena pyriformis, syngen 1. Science 155: 575.

Allen, S. L. (1968). Genetic and epigenetic control of several isozymic systems in Tetrahymena. Ann. N.Y. Acad. Sci. 151 : 190.

Allen, S. L., and Gibson, I. (1967). Genetic homologies and drift within populations of DNA molecules. Science 158: 523 (abst.).

Allen, S. L., and Gibson, I. (1971a). Genetics of Tetrahymena. In Elliott, A. M. (ed.), Biology of Tetrahymena, Appleton-Century-Crofts, Inc., New York (in press).

Allen, S. L., and Gibson, I. (1971b). Intersyngenic variations in the esterases of axenic stocks of Paramecium aurelia. Biochem. Genet. 5: 161.

Allen, S. L., and Lee, P. H. T. (1971). The preparation of congenic strains of Tetrahymena.J. Protozool. (in press).

Allen, S. L., Misch, M. S., and Morrison, B. M. (1963a). Variations in the electrophoretically separated acid phosphatases of Tetrahymena. J. Histochem. Cytochem. 11: 706.

Allen, S. L., Misch, M. S., and Morrison, B. M. (1963b). Genetic control of an acid phosphatase in Tetrahymena: Formation of a hybrid enzyme. Genetics 48: 1635.

Allen, S. L., Byrne, B. C., and Cronkite, D. L. (1971). Intersyngenic variations in the esterases of bacterized Paramecium aurelia. Biochem. Genet. 5: 135.

Britten, R. J., and Kohne, D. E. (1968). Repeated sequences in DNA. Science 161: 529.

Elliott, A. M. (1971). Life cycle and distribution. In Elliott, A. M. (ed.), Biology of Tetrahymena, Appleton-Century-Crofts, Inc., New York (in press).

Margoliash, E., and Smith, E. L. (1965). Structural and functional aspects of cytochrome $c$ in relation to evolution. In Bryson, V., and Vogel, H. J. (eds.), Evolving Genes and Proteins, Academic Press, New York, pp. 221-242.

Markert, C. L. (1968). The molecular basis for isozymes. Ann. N.Y. Acad. Sci. 94: 14.

McCarthy, B. J. (1967). Arrangement of base sequences in deoxyribonucleic acid. Bacteriol. Rev. 31: 215 .

Nanney, D. L. (1967). Comparative corticotype analyses in Tetrahymena. J. Protozool. 14: 553.

Nanney, D. L. (1968). Patterns of cortical stability in Tetrahymena. J. Protozool. 15: 109.

Orias, E. (1959). Mating interaction between varieties 6 and 8, Tetrahymena pyriformis. J. Protozool. 6 (suppl.): 19.

Phillips, R. B. (1968a). Mating type alleles in Illinois strains of Tetrahymena pyriformis, syngen 1. Genet. Res. Camb. 11: 211.

Phillips, R. B. (1968b). Genetic control of acid phosphatase isoenzymes in syngen 7 of Tetrahymena pyriformis. Genetics 60: 211.

Shaw, C. R. (1969). Isozymes: Classification, frequency and significance. Intern. Rev. Cytol. 25: 297.

Shaw, C. R., and Koen, A. L. (1968). Starch gel zone electrophoresis of enzymes. In Smith, I. (ed.), Chromatographic and Electrophoretic Techniques, Vol. II, Heinemann, London, pp. 325-364.

Sonneborn, T. M. (1957). Breeding systems, reproductive methods and species problems in protozoa. In Mayr, E. (ed.), The Species Problem, Am. Assoc. Adv. Sci. Symp., Washington, D.C., pp. 155324.

Walker, P. M. B. (1969). The specificity of molecular hybridization in relation to studies on higher organisms. Progr. Nucleic Acid Res. Mol. Biol. 9: 301. 